\title{
The Impact of Broadhand Microwaves of Sub- and Millimeter Range on Biochemical Metabolism in Experimental Tissue Ischemia in vivo
}

DOI: $10,17691 / \mathrm{stm} 2016.8 .3 .13$

Received May 17, 2016

A.G. Polyakova, MD, DSc, Senior Researcher, Rehabilitation Department;

V.L. Kuzneczova, PhD, Researcher, Biochemistry and Emergency Diagnostics Laboratory;

M.V. Presnyakova, PhD, Senior Researcher, Biochemistry and Emergency Diagnostics Laboratory

Privolzhsky Federal Research Center, Ministry of Health of the Russian Federation,

18 Verkhne-Volzhskaya naberezhnaya, Nizhny Novgorod, 603155, Russian Federation

Electromagnetic radiation (EMR) with various frequency spectra are extensively implemented in practical medicine that determines further experimental studies of the impact on the development of biochemical effects and possible side effects on the body.

The aim of the investigation was to assess the effect of a course of non-thermal microwaves with different broadband frequency ranges on the parameters of the metabolic status of animals in experimental ischemia of a skin flap.

Materials and Methods. We studied the change of necrosis area of distal ischemic dorsal skin flap and the main biochemical indicators in Wistar male rats in the postoperative period, their occipital prominence being exposed to the irradiation in the range 53-78 and 110$170 \mathrm{GHz}$.

Results. The most pronounced vascular effect was recorded when exposed to EMR 110-170 GHz, in this range there are spectra of nitric oxide and oxygen, with the smallest ischemic and necrotic area in a flap compared to the control group of operated animals. The unexposed animals after surgery were found to have high blood glucose and total cholesterol, as well as the elevated concentration of urea in comparison with control animals. The most significant homeostatic effect on biochemical metabolism indices (total bilirubin, urea, total cholesterol and glucose) was recorded under the influence of EMR $53-78 \mathrm{GHz}$.

Conclusion. The exposure of microwaves of sub- and millimeter range in noise radiation mode plays the role of control signals to develop biological effects in the body. No side effects on the body of experimental animals indicates the safe use of microwave exposure.

Key words: electromagnetic radiation; nitric oxide; biochemical metabolism; terahertz band; tissue ischemia.

The development of tissue ischemia is accompanied by the marked disorders of the metabolic status, that is one of the leading causes of unsatisfactory outcomes of reconstructive and restorative treatment. Low-intensity electromagnetic radiation (EMR) of submillimeter (terahertz) and millimeter (extremely high frequencies, EHF) ranges is used as an up-to-date therapeutic corrective physical factor [1, 2].

EMR of $30 \mathrm{GHz}-10 \mathrm{THz}$ is a unique range, as being impeded by the dense atmospheric layers, it does not affect bio-objects from the space and, therefore, they lack adaptation to them [3]. But living organisms generate microwaves themselves and apply this "noiseless range" in the process of intercellular interactions [4]. A distinctive feature of EMR of the given frequency range is the content of molecular spectra of emission and absorption (MSEA) of endogenous bioregulators (molecules-metabolites) in it: $\mathrm{NO}, \mathrm{O}_{2}, \mathrm{H}_{2} \mathrm{O}$, $\mathrm{CO}_{2}, \mathrm{CO}, \mathrm{OH}^{-}$and others, as well as the frequencies of interlevel transitions of the large organic molecules:
DNA, protein and others, that must hypothetically rise the efficiency of the corrective action $[5,6]$.

One of the mechanisms of terahertz therapy effect is connected with nitric oxide, which is a secondary messenger involved in numerous patho- and physiological processes (vasodilatation, neurotransmission, lipid peroxidation, and also in the regulation of smooth muscle tonus, reparative regeneration and so on), which is manifested by the development of polyfunctional systemic influence on the organism [7-9].

Recent investigations in the field of non-thermal (informational) interactions of low-intensity microwaves with the organism allow the researchers to draw a conclusion on the advantages of using noise wideband frequency ranges, which influence the structural transformations of large organic molecules (intensify loop formation in DNA structure), which can change directly the process of biochemical reactions in the development of metabolic effects $[10,11]$. The reaction

For contacts: Alla G. Polyakova, e-mail: ag.polyakova@yandex.ru 
capability of molecules, excited by terahertz quantum is by an order of magnitude greater than that excited by EHF range [12].

However, the main drawback of EMR is the possibility of side-effects and complications in case of using inadequate frequency-energy radiation parameters, that can result in inhibition of physiological reactions - evoke not only dysfunctional, but destructive disorders as well $[13,14]$. This fact shows the necessity of continuing researches to elucidate the mechanism of action, and choosing the safest radiation mode when developing rehabilitating methods of microwave therapy.

The aim of the investigation was to compare the effects of a course exposure to microwaves of nonthermal intensity with various wideband frequency ranges on the parameters of animal metabolic status under the conditions of experimental ischemia of a skin flap.

Materials and Methods. Investigations were carried out in vivo on 32 white male rats of Wistar line weighing 350-400 g. All animals were kept in the standard conditions of vivarium in cages with a free access to food and water according to the State Standard "Maintenance of experimental animals in the nursing areas of Research Institutes" [15]. Microcirculation disturbance was modeled using a modified method of dorsal skin flap dissection that resulted in blood circulation disorders in its distal part. The work was performed in accordance with ethical principles established by European Convention for the Protection of Vertebrata used for Experimental and other Scientific Purposes (the Convention was passed in Strasburg, March, 18, 1986, adopted in Strasburg, June, 15, 2006).

In the course of the study four groups of animals were formed. A control group consisted of intact rats $(n=8)$. The rest of the animals were operated on using intramuscular anesthesia (Zolethyl + Xyla) after picking their fur. A skin pedicle flap with an axial type of blood circulation was dissected from the rat backs and fixed by atraumatic sutures. It caused acute ischemia with necrosis in the distal part of the flap, which made this model suitable for investigating positive and negative effects of physical factors on flap "survival".

In the postoperative period the rats were divided into three experimental groups for comparison. In group $1(n=8)$ animals had been observed after the operation throughout the experiment without any medical procedures. During 7 days the rats of two other groups underwent a course of 10-minutes exposure to EMR in the dose of $0.06 \mathrm{~mJ}$ on the zone of the occipital protuberance near the flap basis, where a projection of the vegetative regulation center responsible for adaptative reactions is located [16].

Animals included into group $2(n=7)$ received EMR with the frequency range $110-170 \mathrm{GHz}$, in which MSEA of nitric oxide and oxygen were present. In group $3(n=9)$ the rats were exposed to the similar EMR in the range
53-78 GHz, where MSEA of the molecules-metabolites were absent.

After operative intervention animals were kept separately. Data on clinical rat examination were recorded before the operation, after it, on day 3 and 7 after the exposure under the control of photo archiving. The area of ischemic damages was registered by overlaying a transparent lined template. Microcirculation dynamics in the operated flap was controlled by a thermovision method using TH-9100 WR Thermo Tracer (NEC, Japan) and laser Doppler flowmetry using LAKK-M laser blood flow analyzer (Lazma, Russia). Observation lasted during 10 days after the operation, till the final formation of necrotic zone with a clear line of demarcation.

A batch-produced device AMFIT-0, 2/10-01 with a noise 53-78 GHz EMR (FizTech, Russia) was used as a source of low-intensity EHF EMR, as well as an experimental model, developed on its basis, with a frequency range $110-170 \mathrm{GHz}$. The power level $(1 \mathrm{~mW})$ and signal spectrum of the device generators were close to the self-radiation of the bio-object that greatly reduces the probability of immediate and delayed side effects. The spectral density of the device noise power $\left(4 \cdot 10^{-17} \mathrm{~W} / \mathrm{Hz}\right)$ was characterized by a high uniformity $( \pm 3 \mathrm{~dB})$ and provided a therapeutically significant signal level at all bio-object resonance frequencies, that suggests repeatability and unambiguity of exposure result interpretation [17]. A cylindrical nozzle was used in such a way, that the distance between the waveguide and the object was $2-5 \mathrm{~mm}$.

Blood for examination of metabolic indices was collected on day 14, when rejection of necroses started; animals were withdrawn from the experiment by decapitation under anesthesia. A biochemical assessment of the probable unfavorable effect of the studied physical factors on the organism was performed using the methods of clinical chemistry, whose data are officially recognized as criteria of toxic and damaging effects [18]. Determination of metabolic parameters of glucose, total bilirubin, urea, creatinine, total protein, albumins, cholesterol, AST, ALT and alkaline phosphatase was carried out using automatic ILAB 650 analyzer (Instrumentation laboratory, USA).

Statistical analysis was performed using Statistica 6.0 program (StatSoft, Inc., USA). Quantitative data were described with the help of the median, the first and third quartiles Me [Q1; Q3]. Independent variables were compared using Mann-Whitney U-test. The results were considered statistically significant at $p<0.05$.

Results and Discussion. In the course of previous investigations we found out, that EMR of EHF and terahertz ranges exerts essential dose-dependent effect on the process of peroxidation of lipids and tissue blood flow $[19,20]$.

After operative intervention a final zone of margin necrosis amounted, on average, to $46.5 \%$ of the flap 
area in animals of group 1. In the rats of experimental groups 2 and 3 , exposed in the postoperative period to EMR of terahertz and EHF-wave range, zones of necrosis appeared comparable and amounted to 26.3 and $31 \%$, respectively. Clinical examination data were similar to those of laser Doppler flowmetry and thermovision, which confirms the influence of microwaves on the vascular link of microcirculation.

The analysis of biochemical adaptation to the conditions of experimental ischemia has revealed changes of the main indices of metabolic status in the rats of different groups, which differed both inter se and in the comparison with the control.

Operation-induced stress caused essential shifts in the content of metabolic products participating in the energy exchange in all animals. In the rats of group 1 the concentration of glucose and total cholesterol in the postoperative period turned out to be statistically significantly higher (almost twice as high) than in intact rats (Table 1).

This may be connected with the fact, that traumatic damage of the tissues stimulates secretion of stress hormones - glucocorticosteroids, which are used to stimulate gluconeogenesis leading finally to hyperglycemia [21].

The total cholesterol was established to be higher in groups 1 and 2 than in the control group. Energy deficiency is known to develop after the operative intervention as a result of tissue damage, lipids being given a special role, as cholesterol is used by the organism as a structural and plastic material for building cell membranes. Its rise is likely to be linked with activation of gluconeogenesis, whose action is directed to the use of lipid exchange products as a source of energy [22, 23].

After a course of radiation the content of glucose and total cholesterol in the rats of group 3, exposed to 53$78 \mathrm{GHz}$ EMR, appeared significantly lower (compared to the control) than similar indices in the blood serum of the animals in groups 1 and 2, which can speak of the homeostasing influence of EHF range of EMR on the energy metabolism indices.

The content of total bilirubin was noted to be lower in groups 1 and 2 compared to the control group. Bleeding caused by the operative intervention was likely to result in the decrease of pigment concentration in the blood

Table 1

Comparative analysis of biochemical indices in the groups (Me [Q1; Q3])

\begin{tabular}{|c|c|c|c|c|}
\hline Analyzed indices & $\begin{array}{c}\text { Control } \\
\text { (intact animals; } n=8 \text { ) }\end{array}$ & $\begin{array}{c}\text { Group } 1 \\
\text { (unexposed; } n=8 \text { ) }\end{array}$ & $\begin{array}{c}\text { Group } 2 \\
(110-170 \mathrm{GHz} ; n=7)\end{array}$ & $\begin{array}{c}\text { Group } 3 \\
(53-78 \mathrm{GHz} ; \mathrm{n}=9)\end{array}$ \\
\hline Glucose (mmol/L) & $\begin{array}{c}13.30 \\
{[12.00 ; 16.65]}\end{array}$ & $\begin{array}{c}24.0 \\
{[22.55 ; 24.90]} \\
p_{1}<0.001\end{array}$ & $\begin{array}{c}22.50 \\
{[2.20 ; 22.60]} \\
p_{2}<0.001 \\
p_{4}>0.5\end{array}$ & $\begin{array}{c}19.70 \\
{[19.60 ; 20.40]} \\
p_{3}<0.02 \\
p_{5}<0.001 \\
p_{6}<0.001\end{array}$ \\
\hline Urea (mmol/L) & $\begin{array}{c}5.05 \\
{[4.05 ; 5.85]}\end{array}$ & $\begin{array}{c}8.60 \\
{[7.85 ; 9.60]} \\
p_{1}<0.001\end{array}$ & $\begin{array}{c}6.40 \\
{[5.10 ; 7.70]} \\
p_{2}>0.05 \\
p_{4}<0.02\end{array}$ & $\begin{array}{c}5.30 \\
{[4.90 ; 5.90]} \\
p_{3}>0.2 \\
p_{5}<0.05 \\
p_{6}>0.05\end{array}$ \\
\hline Creatinine ( $\mu \mathrm{mol} / \mathrm{L})$ & $\begin{array}{c}66.85 \\
{[64.90 ; 68.65]}\end{array}$ & $\begin{array}{c}62.95 \\
{[59.95 ; 66.50]} \\
p_{1}>0.05\end{array}$ & $\begin{array}{c}55.80 \\
{[55.20 ; 60.70]} \\
p_{2}<0.001 \\
p_{4}<0.01\end{array}$ & $\begin{array}{c}68.50 \\
{[67.10 ; 69.40]} \\
p_{3}>0.2 \\
p_{5}<0.05 \\
p_{6}<0.001\end{array}$ \\
\hline Total bilirubin $(\mu \mathrm{mol} / \mathrm{L})$ & $\begin{array}{c}1.63 \\
{[1.570 ; 1.830]}\end{array}$ & $\begin{array}{c}0.90 \\
{[0.755 ; 1.120]} \\
p_{1}<0.02\end{array}$ & $\begin{array}{c}1.09 \\
{[1.00 ; 1.32]} \\
p_{2}<0.01 \\
p_{4}>0.1\end{array}$ & $\begin{array}{c}1.67 \\
{[1.565 ; 2.070]} \\
p_{3}>0.2 \\
p_{5}<0.001 \\
p_{6}<0.001\end{array}$ \\
\hline Total cholesterol $(\mu \mathrm{mol} / \mathrm{L})$ & $\begin{array}{c}1.55 \\
{[1.350 ; 1.700]}\end{array}$ & $\begin{array}{c}2.60 \\
{[2.10 ; 2.90]} \\
p_{1}<0.02\end{array}$ & $\begin{array}{c}2.10 \\
{[1.90 ; 3.10]} \\
p_{2}<0.01 \\
p_{4}>0.5\end{array}$ & $\begin{array}{c}1.70 \\
{[1.60 ; 1.90]} \\
p_{3}>0.1 \\
p_{5}<0.01 \\
p_{6}<0.01\end{array}$ \\
\hline
\end{tabular}

Note s: $\left(p_{1}\right)$ statistical significance of differences of the analyzed parameters in the control group and group $1 ;\left(p_{2}\right)$ in the control group and group 2; $\left(p_{3}\right)$ in the control group and group $3 ;\left(p_{4}\right)$ in groups 1 and $2 ;\left(p_{5}\right)$ in groups 1 and $3 ;\left(p_{6}\right)$ in groups 2 and 3. 
serum due to a small content of erythrocytes [24], which, respectively, reduced their damage. The concentration of bilirubin in the experimental animals exposed to EHFtherapy returned to the norm after the operation.

A substantial increase of urea index (See Figure) in the animals of group 1 is probably to be considered as a reaction of adaptation to the operation stress, occurring together with destructive and inflammatory processes, that is connected with detoxication of excessive quantity of free ammonia - a final product of protein and amino acid exchange [25]. Besides, it was established, that in the rats of groups 2 and 3, exposed to EMR of terahertz and EHF range, the urea

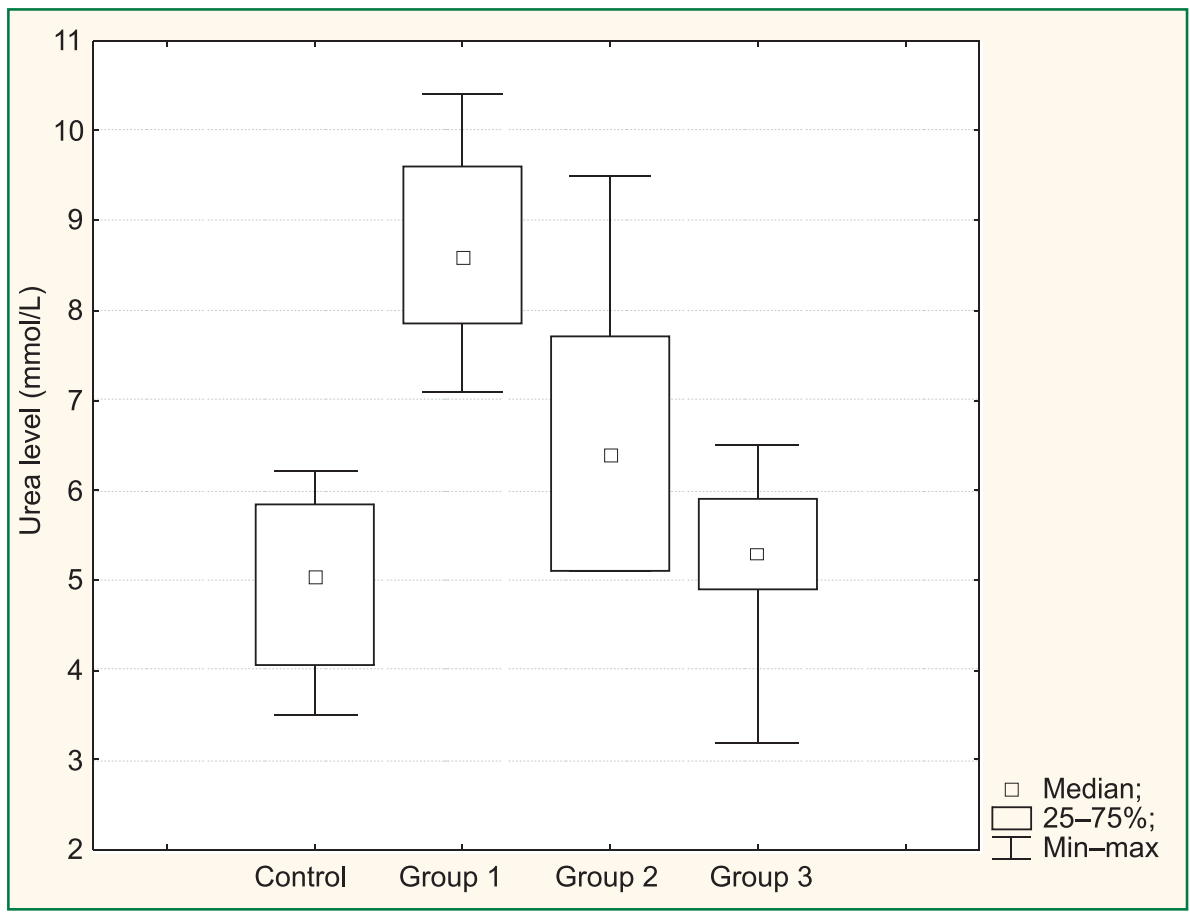

Urea indices in different groups of animals after the operation contents decreased relative to the animals of group 1 in the process of microwave course treatment. This confirms antitoxic and antiinflammatory effects of microwaves (especially that of EHF EMD).

During the study it was found out, that creatinine concentration in groups 1 and 3 did not differ significantly from the values in the control group, whereas in group 2 it was lower. It is likely to be connected with the presence of nitric oxide MSEA in the $110-170 \mathrm{GHz}$ frequency range, when one and the same amino acid, agrinin, participates in the synthesis of nitric oxide and creatinine [26]. The decrease of creatinine in the animals of group 2 is thought by the authors to be connected with the deficiency of this amino acid [27].

When EMR of terahertz range was applied, decrease of total proteins and albumins was also noted in the blood serum of the animals in group 2 (Table 2), which may be associated with the increased protein decomposition to compensate great energy consumption due to the shortage of plastic resources in the organisms of the experimental animals [28].

Statistically significant reduction of ALT index was registered in animals exposed to EHF EMR, and similar tendency was observed in animals undergone EMR of terahertz range compared to group 1 and the control group. Microwaves are known to affect the cell membranes resulting in their structural and functional alterations $[29,30]$. Electromagnetic millimeter waves make the arrangement of lipid molecules more ordered in the cell membrane, increasing the power of hydrophobic interactions both among the lipids and lipidprotein complexes, which leads to the higher membrane

stability. The results obtained may be supposed to be connected with the decrease of membrane permeability, preventing the release of the enzyme to the bloodstream under the action of EHF radiation.

The results of exposure of the animal vegetative regulation centers to a low-intensity wideband EMR of sub- and millimeter range showed, that microwaves influenced favorably the restoration of homeostasis, impaired by the operation stress, which occurs within the frames of general adaptive syndrome. Taking into account the fact, that the sympathetic nervous system provides rapid mobilization of energy resources and activates functional responses to the stimulus, while parasympathetic one corrects and maintains homeostasis, providing reserves for emergency regulation, it may be concluded, that ergotropic and trophotropic function regulation is activated under the action of low-intensity microwaves on the organism.

The comparative analysis of the efficacy of EMR in the given ranges under the conditions of experimental ischemia has demonstrated the paramount influence of 110-170 GHz EMR (the range where MSEA of oxygen and nitric oxide are located) on the vascular link of microcirculation, which is confirmed by the marked reduction of the skin flap necrosis area. In respect to the metabolic correction, the results do not allow us to draw an unambiguous conclusion on the preference of this or that range.

In the group of animals receiving $53-78 \mathrm{GHz}$ EMR a more prominent homeostasing influence was noted with the restoration of initial level of biochemical indices (total bilirubin, urea, total cholesterol) and the tendency 
Table 2

Indices of protein metabolism in the groups (Me [Q1; Q3])

\begin{tabular}{|c|c|c|c|c|}
\hline Analyzed indices & $\begin{array}{c}\text { Control } \\
\text { (intact animals; } n=8 \text { ) }\end{array}$ & $\begin{array}{c}\text { Group 1 } \\
\text { (unexposed; } n=8 \text { ) }\end{array}$ & $\begin{array}{c}\text { Group 2 } \\
(110-170 \mathrm{GHz} ; \mathrm{n}=7)\end{array}$ & $\begin{array}{c}\text { Group } 3 \\
\text { (53-78 GHz; } n=9)\end{array}$ \\
\hline Total protein $(\mathrm{g} / \mathrm{L})$ & $\begin{array}{c}63.8 \\
{[61.10 ; 68.55]}\end{array}$ & $\begin{array}{c}62.6 \\
{[59.75 ; 64.95]} \\
p_{1}>0.2\end{array}$ & $\begin{array}{c}59.0 \\
{[56.2 ; 60.0]} \\
p_{2}<0.01 \\
p_{4}<0.05\end{array}$ & $\begin{array}{c}63.0 \\
{[60.3 ; 65.0]} \\
p_{3}>0.5 \\
p_{5}>0.5 \\
p_{6}<0.01\end{array}$ \\
\hline Albumins ( $\mathrm{g} / \mathrm{L})$ & $\begin{array}{c}23.9 \\
{[22.70 ; 25.95]}\end{array}$ & $\begin{array}{c}22.7 \\
{[22.10 ; 25.10]} \\
p_{1}>0.2\end{array}$ & $\begin{array}{c}20.3 \\
{[19.7 ; 22.4]} \\
p_{2}<0.01 \\
p_{4}>0.05\end{array}$ & $\begin{aligned} 22.7 \\
{[20.80 ; 23.80] } \\
p_{3}>0.2 \\
p_{5}>0.2 \\
p_{6}>0.2\end{aligned}$ \\
\hline Globulins (g/L) & $\begin{array}{c}39.8 \\
{[37.30 ; 43.60]}\end{array}$ & $\begin{array}{c}38.9 \\
{[37.35 ; 41.50]} \\
p_{1}>0.5\end{array}$ & $\begin{array}{c}36.4 \\
{[35.8 ; 40.4]} \\
p_{2}>0.05 \\
p_{4}>0.2\end{array}$ & $\begin{array}{c}41.3 \\
{[39.20 ; 41.80]} \\
p_{3}>0.5 \\
p_{5}>0.2 \\
p_{6}>0.05\end{array}$ \\
\hline AST (units/L) & $\begin{array}{c}157.1 \\
{[121.9 ; 169.8]}\end{array}$ & $\begin{array}{c}148.5 \\
{[138.8 ; 203.2]} \\
p_{1}>0.2\end{array}$ & $\begin{array}{c}189.6 \\
{[149.3 ; 228.9]} \\
p_{2}>0.2 \\
p_{4}>0.2\end{array}$ & $\begin{array}{c}146.5 \\
{[106.8 ; 164.4]} \\
p_{3}>0.2 \\
p_{5}>0.2 \\
p_{6}>0.05\end{array}$ \\
\hline ALT (units/L) & $\begin{array}{c}72.7 \\
{[59.8 ; 85.5]}\end{array}$ & $\begin{array}{c}81.1 \\
{[56.6 ; 88.8]} \\
p_{1}>0.2\end{array}$ & $\begin{array}{c}61.2 \\
{[57.9 ; 75.7]} \\
p_{2}>0.2 \\
p_{4}>0.2\end{array}$ & $\begin{array}{c}53.1 \\
{[50.3 ; 59.0]} \\
p_{3}<0.01 \\
p_{5}<0.01 \\
p_{6}>0.05\end{array}$ \\
\hline
\end{tabular}

Note s: $\left(p_{1}\right)$ statistical significance of differences of the analyzed parameters in the control group and group 1; $\left(p_{2}\right)$ in the control group and group 2; $\left(p_{3}\right)$ in the control group and group 3; $\left(p_{4}\right)$ in groups 1 and $2 ;\left(p_{5}\right)$ in groups 1 and $3 ;\left(p_{6}\right)$ in groups 2 and 3.

to normalization of the glucose level in the postoperative period.

A negative effect of the irradiated physical factors on the state of the tissue bloodstream and biochemical indices has not been found.

Conclusion. The exposure to microwaves of sub- and millimeter range in the noise radiation mode plays the role of control signals in the development of biological effects in the body. Absence of side effects on the body of the experimental animals testifies to the safe use of microwave exposure.

Study Funding and Conflicts of Interest. The work was not funded by any source, and there are no conflicts of interest related to this study.

\section{References}

1. Ponomarenko G.N. Innovative restoration technology. Kurortnye vedomosti 2010; 5(62): 15-18.

2. Istomina I.S. EHF therapy in clinical practice (Part II). Fizioterapiya, bal'neologiya i reabilitatsiya 2012; 6: 38-45.
3. Savel'ev I.V. Kurs obshchey fiziki. T. 4. Volny. Optika [The course of general physics. Vol. 4. Waves. Optics]. Saint Petersburg: Lan'; 2011; 256 p.

4. Kulipanov G.N. Generation and application of terahertz radiation: history and perspective. Vestnik Novosibirskogo gosudarstvennogo universiteta. Seriya: Fizika 2010; 5(4): 2427

5. Ramundo Orlando A., Gallerano G.P. Terahertz radiation effects and biological applications. J Infrared Milli Terahz Waves 2009; 30(12): 1308-1318, http://dx.doi. org/10.1007/s10762-009-9561-z.

6. Fedorov V.I. Study of biological effects of electromagnetic radiation of submillimeter part of terahertz range. Biomeditsinskaya radioelektronika 2011; 2: 17-27.

7. Parshina S.S., Afanas'eva T.N., Tupikin V.D. Biological effects of nitrogen oxide in cardiovascular pathology development as the basis of terahertz therapy application. Byulleten' meditsinskikh internet-konferentsiy 2012; 2(6): 446452.

8. Gapeyev A.B. Study of the mechanisms of biological effects of low-intensity extremely high-frequency electromagnetic radiation: progress, problems and prospects. Biomeditsinskaya radioelektronika 2014; 6: 20-30. 
9. Ivanov A.N. Regulatory effects of wave terahertz frequencies. Byulleten' meditsinskikh internet-konferentsiy 2012; 2(6): 392-399.

10. Bogomolova N.V., Dulatov R.M., Kireev S.I., Kirichuk V.F., Krenitskiy A.P. Complex experimental and clinical investigation of the effectiveness of electromagnetic radiation therapy of terahertz range at the frequencies of molecular spectrum of nitric oxide in rehabilitation of patients with bone fractures. Vestnik novykh meditsinskikh tekhnologiy 2010; 17(1): $107-110$.

11. Tsurkan M.V., Sobakinskaya E.A., Smolyanskaya O.A., Bespalov V.G., Vaks V.L., Balbekin N.S. Spectrum research of DNA molecule in the terahertz frequency domain. Nauchnotekhnicheskiy vestnik informatsionnykh tekhnologiy, mekhaniki i optiki 2012; 1(77): 15-19.

12. Tsymbal A.A., Kirichuk V.F., Krenitsky A.P., Betsky O.V. Restoration of the main indicators of the metabolic status of terahertz waves at frequencies of nitric oxide 150.176 ... $150.664 \mathrm{GHz}$ in the experiment. Biomeditsinskaya radioelektronika 2011; 1: 30-35.

13. Kazarinov K.D. The biological effects of the electromagnetic field in the terahertz range. Elektronnaya tekhnika. Seriya 1: SVCh-tekhnika 2009; 503(4): 48-58.

14. Rybalko S.Y., Yashchenko S.G., Kolbasin P.N. Moring effects of the low-intensity electromagnets radiation and morphological changes of human blood erythrocytes. Tavricheskiy mediko-biologicheskiy vestnik 2013; 16(1-2): 170-173.

15. Ploskonos M.V. Influence of millimeter electromagnetic radiation of low intensity on apoptosis of male germ cells. Uspekhi sovremennogo estestvoznaniya 2015; 1-6: 974-976.

16. Rukovodstvo po laboratornym zhivotnym $i$ al'ternativnym modelyam $v$ biomeditsinskikh issledovaniyakh [Guidelines on laboratory animals and alternative models in biomedical studies]. Pod red. Karkishchenko N.N., Gracheva S.V. [Karkishchenko N.N., Grachev S.V. (editors)]. Moscow: Profil' - 2S; 2010; 358 p.

17. Krylov V.N. The effect of low-intensity EMP extremely high-frequency band on some homeostasis indices in animals. Vestnik Nizhegorodskogo universiteta im. Lobachevskogo. Seriya: Biologiya 2003; 1(6): 14-24.

18. Betskii O.V., Lebedeva N.N., Yaremenko Yu.G. Equipment for EHF-therapy. Radiotekhnika 2007; 3: 4-15.

19. Klinicheskaya laboratornaya diagnostika (metody i traktovka laboratornykh issledovaniy) [Clinical laboratory diagnostics (techniques and interpretation of laboratory investigations)]. Pod red. Kamyshnikova V.S. [Kamyshnikov V.S. (edior)]. Moscow: MED-press-inform; 2015; 720 p.

20. Polyakova A.G., Soloveva A.G., Sazonova I.E., Zakharova D.V. Influence of electromagnetic radiation of extremely high frequencies on proand antioxidant status of blood in the experiment. Biofizika 2016; 61(1): 131-137.

21. Polyakova A.G., Sazonova J.E., Volovik M.G., Peretyagin P.V., Zakharova D.V. The influence of low intensity EMR on the state of tissue blood flow in the skin loskute of rats. Vestnik vosstanovitel'noy meditsiny 2014; 6(64): 25-31.

22. Tsymbal A.A., Kirichuk V.F., Antipov O.N., Kurturova M.O., Andronov E.V. Changes in the level of corticosterone in the blood of experimental animals exposed to terahertz waves at a frequency of atmospheric oxygen $129.0 \mathrm{GHz}$ on a background of acute and prolonged stress. Biomeditsinskaya radioelektronika 2011; 8: 23-28.

23. Roslyy I.M. Biokhimicheskie pokazateli $v$ meditsine $i$ biologii [Biochemical parameters in medicine and biology]. Moscow: Meditsinskoe informatsionnoe agentstvo; 2015; $616 \mathrm{p}$.

24. Khiggins K. Rasshifrovka klinicheskikh laboratornykh analizov [Interpretation of clinical laboratory tests]. Pod red. Emmanuelya V.L. [Emmanuel' V.L.]. Moscow: BINOM. Laboratoriya znaniy; 2013; 456 p.

25. Ostapchuk A.E. Bilirubin. 2013. URL: http://youpedia.ru/ medicina-b/bilirubin.html.

26. Obmen serosoderzhashchikh aminokislot - metionina $i$ tsisteina [Exchange of sulphur-containing amino acids: methionone and cysteine]. URL: http://biofile.ru/bio/10604.html.

27. Kuznetsova V.L., Solov'eva A.G. Nitric oxide: properties, biological role, mechanisms of action. Sovremennye problemy nauki i obrazovaniya 2015; 4. URL: http://www.scienceeducation.ru/ru/article/view?id=21037.

28. Severin E.S., Aleynikova T.L., Osipov E.V., Silaeva S.A. Biologicheskaya khimiya [Biological chemistry]. Moscow: Meditsinskoe informatsionnoe agentstvo; 2008; 364 p.

29. Kirichuk V.F., Tsymbal A.A. Patterns and mechanisms of the physiological effects of terahertz waves at frequencies of active cellular metabolites. Biomeditsinskaya radioelektronika 2014; 5: 61-66.

30. Polyakova A.G., Aleinik D.Ya. Influence of low intensity microwaves on cellular activity of dermal fibroblasts of different genesis. Vestnik Nizhegorodskogo universiteta im. N.1. Lobachevskogo 2013; 6(1): 146-152. 